\title{
Yeni Anayasa Tartışmaları Etrafında Kurucu İktidar, Kurucu Meclis ve Referandum Kavramlarının Analizi
}

\author{
Ahmet NOHUTÇU* \\ Mücahit BEKTAŞ ${ }^{* *}$
}

\section{Öz}

Kıta Avrupası ve Anglo-sakson ülkelerinde çıkıp olgunlaşan "kurucu iktidar", "kurucu meclis" ve "referandum" tartışmaları, salt ve sınırlayıcı hukuk anlayışının ötesinde siyaset teorisi etrafında şekillenmiştir. Halkın kendi kendini yönetmesi olan demokrasi, kurucu iktidarı, yani egemenliği halka ait görmektedir. Fakat genel görüşün aksine Türkiye'deki tartışmalar, anayasa hukukunun siyasal yönünün göz ardı edildiği ve bu yüzden vesayetçi bir yaklaşımla anti-demokratik ve statükocu yönü ağır basan bir seyir içerisine girmiştir. Kendilerini kurucu değerlerin muhafızları olarak gören vesayetçi elitlerin başını çektiği bu görüş, kimi hukukçular tarafından da desteklenmiştir. Demokratik yollarla ve halkın talepleri doğrultusunda yeni bir anayasa oluşturmak da dâhil, tüm anayasal düzenlemeler bu elitler tarafından gayrimeşru gösterilmeye çalışılmaktadır. Ancak başta referandum ve diğer demokratik kanallarla soyut bir kavram olan kurucu iktidar olgusunun, halkın temsilcileriyle somutlaşmasının demokrasinin asli unsurlarından olduğu unutulmuştur.

$\mathrm{Bu}$ doğrultuda hem devletin hukuki statüsünü belirleyen hukuki bir belge, hem de devletin asli organlarını ve aralarındaki ilişkiyi belirleyen kurucu bir siyaset belgesi niteliğinde olan anayasanın, sadece olağanüstü ve hukuk-dışı ortamların bir ürünü olmadığı, demokratik ve barışçl yollarla da yeni bir anayasa oluşturulabileceği, hatta bu yöntemin demokratik olması açısından diğerine göre daha meşru olduğu sonucuna ulaşılmıştır.

Anahtar kelimeler: Kurucu iktidar, Kurucu meclis, Anayasa, Referandum, Demokrasi.

\section{An Analysis of Constituent Power, Constituent Assembly and Referendum Concepts around the New Constitution Discussions}

\footnotetext{
Abstract

Debates about "constituent power", "constituent assembly" and "referendum", which have emerged and developed in continental Europe and Anglo-Saxon countries, revolves around political theory beyond

* Prof. Dr., İstanbul Medeniyet Üniversitesi, Siyasal Bilgiler Fakültesi, Siyaset Bilimi ve Kamu Yönetimi Bölümü, anohutcu@yahoo.com

** Araş. Gör., Recep Tayyip Erdoğan Üniversitesi, İktisadi ve İdari Bilimler Fakültesi, Siyaset Bilimi ve Kamu Yönetimi Bölümü, mucahitbektas1@gmail.com
} 
pure and restrictive understanding of law. Meaning self-governance of people, democracy, regards constituent power, or sovereignty, as residing within people. Contrary to general understanding, however, discussions in Turkey ignore the political aspect of constitutional law, thus turn into a tutelage approach underlined by anti-democratic and status quo favoring features. Even some jurists supported this view which is held by self-appointed guardians of founding principles and tutelage favoring elites. These elites try to present all constitutional arrangements as illegitimate including creation of a new constitution via democratic means in accordance with demands of the people. Nevertheless, it is forgotten that through referendum, particularly, and other democratic channels, the solidification of phenomenon of power, which is an abstract term, with representatives of people is one of the fundamental components of democracy.

In this respect, it is concluded that as a legal document designating state's legal status and a founding political document designating essential organs of state and the relations between them, constitution is not only a product of extraordinary and extrajudicial settings, a new constitution can be created via democratic and peaceful means too and this way is more legitimate than the former in terms of being democratic.

Keywords: Constituent Power, Constituent Assembly, Constitution, Referendum, Democracy.

\section{Giriş}

Günümüz dünyasında, ülkelerin yönetimlerinin demokratik olup olmadıkları, demokratikse ne denli halk egemenliğine dayandığı soruları bir karşılaştırma ve değerlendirme unsuru olarak kullanılmaktadır. Dünya siyasetinin bir amentüsü haline gelen demokrasi, ülkelerin birbirleriyle olan diplomatik ilişkilerinden ticari ilişkilerine kadar pek çok alanda gündeme gelmektedir. Yakın zamanda demokratik olmadıkları gerekçeleriyle birçok ülkeye ekonomik, siyasi, mali vb. ambargolar uygulanmış ve hatta askeri müdahaleler gerçekleşmiştir.

Demokrasinin olmadığı iddia edilen ülkelerin siyasal sistemlerine bakıldığında, temsili demokrasinin şekilsel tüm gereklerinin yerine getirildiği görülmektedir. Seçmenlerin eşit ve genel oy ilkesiyle seçimlere katıldığı ve adaylarını seçtikleri demokratik seçimler ve süreçlerin bu ülkelerde uygulanmadığını söylemek mümkün değildir. Hatta yüzde seksen yahut doksanlara varan oy oranlarıyla iktidar olan partilerin varlığı da inkâr edilemez. Ancak yukarıda belirtilen şartlara sahip ülkelerin demokratik olmadıklarını, demokrasinin tam anlamıyla işlemediği de reddedilmesi son derece güç bir gerçektir.

O halde demokrasi yalnızca genel oy ilkesine göre seçimlerin yapılıyor olması anlamına gelmemektedir. Seçimler, demokrasinin gerçekleştirilmesi adına birer araçtır. Demokrasi, halkın kendi kendini yönetmesi, kendi kaderini tayin etmesi ve kendisi hakkında karar alması anlamına gelmektedir. Dolayısıyla demokrasinin gerçekleştirilmesi adına kullanılan araçların asli unsur olarak görülmesi, demokrasinin özü olan halkın egemenliği ilkesine aykırılık teşkil etmektedir. Binaenaleyh, makalede, bu ana fikir etrafında demokrasinin, yani halk egemenliğinin tam manasıyla vücut bulması için yapılması gerekenleri ele alınacaktır. 
Makale "Yeni bir anayasa yapmak da dâhil olmak üzere tüm anayasal düzenlemelerin demokratik meşruiyeti haiz anayasal kurumlarca yapllabileceği ve bu tür girişimlerin demokrasinin özüne, şartlarına ve mekanizmalarına uygun olduğu” tezini savunmaktadır. Bu doğrultuda ilk başlıkta "kurucu iktidar", "kurucu meclis" ve "kurucu yasa" olarak anayasa, kavramsal ve teorik çerçevede ele alınmıştır. Böylece tartışma zemininin doğru bir şekilde oluşturulması amaçlanmıştır. Literatürde kullanılan kavram setinin analiz edilmesinin ardından Türkiye'de yürütülen kurucu iktidar tartışmaları irdelenecektir. Böylece kavramların aslına ne kadar bağlı kalınıp kalınmadığı gösterilmeye çalışılacaktır. Anlaşılacağı üzere, ilk iki başlık birbirini tanımlayıcı bir özellik taşımaktadır. Özellikle, Türkiye'deki güncel anayasa tartışmalarına, "Kurucu İktidar, Kurucu Meclis ve Kurucu Yasa” ve "Türkiye'de Kurucu İktidar Tartışmaları" başlıklarının, kavram kargaşasına son vermeyi amaçlaması açısından farklı bir boyut kazandıracağı düşünülmektedir.

Son olarak, "Kurucu İktidarın Temsili Sorunu ve Referandum" başlı̆̆ında ise dünyada ve Türkiye'de yürütülen "kurucu iktidarın temsili” tartışmalarına, alternatif bir cevap olarak görülen "referandumun" çeşitli boyutlarıyla analiz edilmesi amaçlanmıştır. Tartışmanın ve yöneltilen eleştirilerin ardından bir çözüm önerisi yahut alternatif sunulmasının akademik gerekliliğine olan inanç bu başlığın kaleme alınmasına neden olmuştur. Aksi halde kaleme alınan çalışmanın akademik ve toplumsal bir faydasının tam anlamıyla görmesinin zor olduğu düşünülmektedir.

\section{Kavramsal Çerçeve: Kurucu İktidar, Kurucu Meclis ve Kurucu Yasa}

Son birkaç yüzyıl içerisinde bilim dünyasının, felsefecilerin ve uygulayıcıların üzerinde en çok fikir yürüttüğü konuların başında anayasa gelmektedir. Tartışmalar anayasanın ne olduğu, neleri kapsadığı veya kapsamadığı, kim tarafından oluşturulduğu veya oluşturulması gerektiği gibi temel sorular etrafında yürütülmektedir. Amaç, kökeni Türkçe olmayan bir kelimenin Türkçe çevirisi üzerinden semantik bir analiz yapmanın ötesidir.

Türkiye özelinde kimi elitist siyasetçiler, yazarlar veya hukukçular 'anayasa', 'kurucu iktidar' ve 'kurucu meclis' gibi kelimelere (Akkanat, 2015) transandantal (aşkın) bir anlam yükleyerek, yeni baştan bir anayasa oluşturulabilmesi için olağanüstü yetkilerin ve durumların yani darbe, devrim, savaş ve kaosun gerekliliğine vurgu yapmaktadırlar. Bu şartların dışında mevcut bir anayasal düzen içerisinde yeni baştan bir anayasa oluşturulamayacağı savunularak statükocu bir anlayış benimsenmektedir. Kısaca, demokratik ve barışçı yollar ile 'kurucu/asli iktidar' olunamayacağını söyleyerek âdeta anti-demokratik uygulamaları meşru görmektedirler. Böylece, demokrasi yanlısı grupların, anayasayı yeniden oluşturma başta olmak üzere, herhangi bir mevcut düzeni değiştirecek düzenlemeleri uygun görülmemektedir (Hekimoğlu, 2007, s. 8-9; Gözler, 1998; 2012, s. 45-48; 2004, s. 29-41; Özmen \& Özdemir, 2011, s. 870-871).

Bu başlıkta, kurucu iktidarın halk, anayasanın kurucu belge ve yapıcısının ise kuruculuk yetkisini halktan alan meşru meclis olduğu tezi analiz edilip tartışılacaktır. Dolayısıyla bu başlık altında temel kavramların orijinal kökenleri hem semantik hem de teorik bir anlayışla analiz edilmiş, Türkçe literatürdeki kasıtlı yahut kasıtsız yanlış anlamlandırmaların önüne 
geçilmesi amaçlanmıştır. Kavramların özünün doğru anlaşılması bunlar üzerinden yürütülen tartışmaların sağlıklı yürütülebilmesi için hayati önem taşımaktadır. Bu amaç doğrultusunda ise "Toplum Sözleşmesi” teorisinden günümüz anayasa (kurucu belge/yasa/ittifak) teorilerine kadar anlatımsal bir yaklaşım kullanılmıştır (Güler, 2007, s. 35). Böylece anayasa teorileri etrafında yapılan tartışmaların ekseriyetle "yanlış" ya da "temelsiz" bir zemine oturtulduğu gösterilmeye çalışılmıştır.

Toplum sözleşmesi, bazı siyaset felsefecilerinin (Hobbes, Locke, Rousseau gibi) toplumun, daha sonrasında da devletin varoluşuyla ilgili ürettikleri kurgusal bir başlangıç noktasını oluşturmaktadır (Dworkin, 1986, s. 164; 1973, s. 500; Loughlin, 2014, s. 221). Doğa durumundan çıkışın ve siyasi bir oluşumun miladı olarak kabul edilen toplum sözleşmesi, insanların huzur ve refah içerisinde yaşayabilmeleri için hem kendilerinden hem de dışarıdaki diğer insanlardan korunmak maksadıyla uzlaştıkları, birlik oldukları ve kendilerini sınırladıkları varsayımına dayanmaktadır (Gauthier, 1977, s. 134-135). Bir toplum dahası sivil bir toplum meydana getiren sözleşme; egemenlik, adaletin sağlanması için kurallar veya ahlaki edimlerle dini görev, kişisel güvenlik ve refah gibi farklı amaçlara sahip olsa da temelde bir bütün olma tercihine karşılık gelmektedir (Çetin, 2002a, s. 1-9; 2002b, s. 57). Bu geniş perspektiften bakıldığında siyasal/sivil bir oluşum olarak toplum üzerinden yapılan tartışmaların veya yürütülen fikirlerin Rönesans’tan (Öztürk, 2013) Antik Yunan’a kadar geri gittiği görülmektedir (Loughlin, 2014, s. 219-221). Ancak nihayetinde dile getirilen fikirler birlik-bütün olma yönünde yapılan bir tercih olduğu etrafında dönmektedir (Boucher \& Kelly, 1994, s. 2-3).

Kökenlerini, Antik Yunandan Aydınlanma Çağına kadar süren toplumsal sözleşme teorilerinden alan anayasa kavramı diğer dillerde orijinaline sadık kalınarak (Konstitution, Constitution, Costituzione, Constitutio, Constitución) kullanılmaktadır. Kelimenin kökeni incelendiğinde "yapı, karakter, oluşturma” gibi anlamlara geldiği görülmektedir (Küçükkaya, 2011, s. 2-3). Örneğin konuyla ilgili Schmitt'in tanımlamasında "halkın siyasal birliği anayasayı, devlet ise bu birliğin/anayasanın somutlaşmış halini” temsil etmektedir. Bu anlamda Schmitt (2008, s. 59) kelimeyi geniş anlamda herkesi ve her şeyi kapsayan "yapi" ve dar anlamda ise "halkın politik birliği” olarak tanımladığı ifade edilebilir. Schmitt'in tanımlaması elbette ki yalnızca bundan ibaret değildir. Kavramı çeşitli yönleriyle ele almakta ve açıklamaktadır (Schmitt, 2008, s. 59-66). Ancak pratik sebeplerden dolayı tüm boyutları veremeyeceğimizden, temel kavramsallaştırmaya burada yer verilmiştir. Türkiye’deki teorik tartışmaların 'ana' yasa, 'temel' yasa gibi vurgular üzerinden şekillendiğini hatırlanacak olursa (Turinay, 2011, s. 273-278), anayasa teorilerinin menşei olan demokratik ülkelerdeki tartışmalardan ne kadar uzakta olduğu da görülecektir. Kısaca, halk egemenliğinin en iyi şekilde nasıl temsil edilebileceği yönündeki demokratik tartı̧̧maların ihmâl edilip, teorik tartışmaların dışında ağırlıklı semantik tartışmaların yapıldığı söylenebilir.

Yukarıdaki yaklaşımlardan da anlaşılacağı gibi, kurucu iktidar ile halk bir bütünü oluşturmaktadır. Bu açıdan Cristi (1997), Schmitt'in kurucu iktidar ve egemenlik üzerinden kurduğu anayasa teorisini oldukça iyi analiz etmiştir. Schmitte göre, kurucu iktidar, yani halk egemenliği sürekli bir şekilde ortaya çıkıp kurucu belge oluşturmamaktadır. Ancak halk egemenliğini temsil etmeyen, 
parlamenter yahut monarşi yanlısı olsun veya olmasın herhangi bir siyasi oluşumun meşruiyetini halktan almayışı, kurucu iktidar olarak halkın ortaya çıkmasına engel olmaktadır. Yani halka ve halkın egemenliğine dayanmayan, bu yönüyle meşru bir gücü temsil etmeyen hiçbir oluşumun anayasa oluşturamayacağını ifade etmektedir (Cristi, 1997, s. 195-196). Özetle, Schmitt, anayasa teorisini halk egemenliğine dayandırmakta (Böckenförde, 1997, s. 9) ve demokratik amaçlar doğrultusunda da olsa siyasal birlik olarak halkın gerçek temsilinin sağlanmamasını (yani kurucu iktidar olarak halkın kabul edilmemesi), diktatörlük olarak görmektedir (Cristi, 1997, s. 197198).

Ancak ana hatlarıyla verilen Schmitt'in anayasa teorisinin yukarıda da ifade edildiği üzere 'bazı özel şartları' gerektiriyor ve belli oranda statükocu bir özellik taşıyor olması, tezimiz açısından sorunlu olmaktadır (Göztepe, 2015, s. 176). Buna göre kurucu iktidar halk egemenliğine dayanıyor olmakla beraber, kurulmuş bir iktidarın yıkılarak yeni bir iktidar kurulması özel şartlar' gerektirmektedir (Schmitt, 2008; Stacey, 2011, s. 587-588). Muhafazakâr veya tutucu bir izlenim veren bu düşüncenin (Preuss, 1993, s. 639) aksine Demirkent’in (2015) oldukça iyi bir şekilde mukayese ettiği gibi Arendt, Schmitt gibi halk egemenliğini kurucu iktidar olarak görmekte, ancak onun aksine, özel bir şart gerekmeksizin halkın her daim kurucu olarak anayasayı düzenleyebileceğini savunmaktadır (Demirkent, 2015, s. 89,93). Yine Demirkent' in özetlediği gibi Arendt, Fransız Devrimini değil Amerikan Devrimini örnek kurucu eylem olarak sunmaktadır. Kurucu olmanın transandantal bir imge olmaktan çıkarılması ve halk ile uygulayıcıların sürekli etkileşim halinde, kurma eylemine devam etmesi gerektiğini ifade eder. Ayrıca devletin şiddet üzerine kurulu olduğu fikrine karşı gelerek, Amerika'da olduğu gibi müzakereyi esas almaktadır (Demirkent, 2015, s. 94-95; Kalyvas, 2005, s.231).

Hem Schmitt hem de Arendt'in halk egemenliğini kurucu iktidar olarak kabul ettiği yukarıda belirtilmişti. Bu kabulün yanında kurucu iktidarın ne katı bir durağanlık ne de sınırsız bir dönüşüm içerisinde olduğu, gerektiği durumlarda kurucu iktidarın kurma yetkisini kullanabileceği benimsenmektedir (Can 2007, s. 105-106). Daha net ve günümüz şartları ile ifade edersek, toplumun tamamını kapsayamasa da büyük bir çoğunluğunun 'istekleri' doğrultusunda ve geri kalanların lehine olmasa da aleyhine olmayan düzenlemelerin (bunlar yeni baştan kurmakla kısmen değiştirmeği de kapsayabilir) yerine getirilebilmesi için halkın temsilcileri, kurucu iktidarın verdiği yetkiyi referandum ve diğer demokratik müzakere yollarıyla birlikte kullanabilmelidirler (Colón-Ríos, 2014; 2010, s. 235-236).

Elbette, bu noktada ortaya çıkan halk egemenliği ve anayasa/hukuk ile demokrasi, insan hakları, eşitlik, çoğulculuk ve özgürlük arasındaki tartışmalı durum göz ardı edilmemektedir (Habermas, 1995; Dworkin, 1995; Corrias, 2016, s. 9-12). Arendt ve Schmitt arasındaki ayrımın da bu noktada ortaya çıktığını görmekteyiz. Egemenlik kavramının demokratik olmayan yorumlarının da olduğu tarihsel deneyimlerden bilinmektedir. Arendt'e göre egemenliğin demokratik ve halka dayalı olmasının yanında durağan bir nitelik taşımaması da gerekmektedir. Aksi halde eskinin demokrat kurucusu, geleceğin monarşisi haline gelecektir. Dolayısıyla halk egemenliğinin ve kurucu iktidarın tek bir zamansal boyuta saplanıp kalması, 
kendinden sonraki kurucu iktidarın (halkın) egemenlik haklarını gasp edeceğinden antidemokratik nitelik taşır (Spång, 2014, s.109; Dyzenhaus, 2007, s.120). Yani daha açı bir ifade ile Schmitt' in (2008) siyasal birliğin egemenliğinin somutlaşmış şekli olarak anayasa, bu birliği oluşturan parçaların veya birliğin tamamının durağan olmadığı, dönüşüm içerisinde olduğu gerçeği karşında kendisinin de dönüşebilir olmasını mantıksal olarak zorunlu kılmaktadır (Loughlin \& Walker, 2007, s. 2).

Kurucu iktidar ve halk egemenliği kavramlarının teorik tartışmalarının yanında ve bu teorik tartışmalara argüman olarak kullanılan pratik karşılıklarına bakmak yararlı olacaktır. Çünkü teorik zeminde 'kurucu iktidar' tartışılırken, pratik zeminde kurucu iktidarın yansıması olan 'kurulmuş iktidar veya kurucu meclis' tartışılmaktadır. Kısaca, soyut bir kavram olan kurucu iktidar böylece somutlaşmaktadır. İngiltere, halk egemenliğinin, anayasal sürecin ve demokratikleşmenin yerleşmesinde oldukça önemli bir yere sahiptir. Magna Carta’dan günümüz anayasal düzenine (yazılı bir anayasası olmasa da anayasal bir düzen olduğu inkâr edilemez) kadar olan sürecin halkın temsilcisi ve halk adına anlayışılla şekillendiği görülmektedir (Loughlin, 2007, s. 34). Bu durum öyle kurumsallaşmıştır ki, Erhürman’’n (2013) makalesinde işlediği üzere, parlamentonun üstünde bir güç tanınmamakta, önceki parlamentonun dahi sonraki parlamentoyu kısıtlayıcı kararlar alması engellenmektedir. İlgili kısım aynen aktarılacak olursa:

"Parlamento egemenliği (veya parlamento üstünlü̆̈̈̈) ilkesi Birleşik Krallk Anayasasinnn temel ilkesi olarak kabul edilmektedir. Bu ilkeye göre, Birleşik Krallk Parlamentosu her türlü yasayı yapmaya yetkilidir ve Birleşik Krallık'taki hiçbir organ veya kişi Parlamento tarafindan yapilan bir yasayı yürürlükten kaldrramaz ve iptal edemez. Ayrica, bu ilkenin doğal bir sonucu olarak, herhangi bir parlamento, kendisinden sonraki parlamentolar bağlayacak bir yasa yapma yetkisine sahip değildir" (Erhürman, 2013, s. 257).

Amerika ise kurucu iktidar teorilerinde özel bir yer tutmaktadır. Bu özelliği hem yapılış yönteminden hem de demokratik niteliklerinden kaynaklanmaktadır. Amerikan Anayasası, anayasal sözleşmeyle halkın temsilcilerinin halkın egemenliğinden aldıkları güçle meydana gelmiştir. Yani demokratik yollarla halk egemenliğinin temsilcisi (o dönem için genel oy ilkesinin geçerli olmadığını, kölelerin, kadınların vb. grupların dâhil olmadığını unutmamak gerekir) konumunda olanlar anayasayı yazmışlardır. Herhangi bir savaş ve kaos durumunun oluşturduğu otorite boşluğundan yararlanıp, oluşturulmamıştır (Griffin, 2007; Klein, 1978, s. 203-205).

Anayasa ve siyaset teorisyenleri için kurucu iktidar kavramının teorik zemininin oturtulmasında önemli bir yer tutan Amerikan örneğinin yanında, salt prosedürü amaçlayan ve bu doğrultuda düşünen hukukçular içinse Fransa ve Almanya örnekleri oldukça önemli bir yer tutmaktadır. Özellikle Türkiyedeki bazı anayasayla ilgilenen hukukçuların bunların başında geldiği söylenebilir.

Fransảnın anayasa ve kurucu iktidar teorileriyle ilgili örneği 1789 devrimi ile başlamaktadır. Halkın kurucu iktidar olarak siyasal alana girmesiyle ortaya çıkan anayasa tartışmalarının 'kurucu iktidar kimdir?' sorusundan çok, kurumlar üzerinden bu ilişkinin nasıl sağlayacağına 
yoğunlaşmaktadır. Kısaca, Fransa örneğinde kurucu iktidar, 'halk' kabul edilmiş ve halk egemenliği ile onu temsil eden kurumların ne olması, nasıl kurgulanması ve hangi yetkilerle donatılıp, denetlenmesi gerektiği tartışmaların merkezinde yer almıştır. Yoğun olarak ilk yüz içinde gerçekleşen bu tartışmalar daha sonra De Gaulle ile birlikte farklı bir boyut alarak, halk egemenliğinin somut, doğrudan ve güçlü temsil edilmesi gerektiği görüşü hâkim olmuştur (Jaume, 2007, s. 67-68). Anlaşılacağı üzere, Fransa, verilen örneklerin aksine kurucu iktidarı halk egemenliği olarak görür ve anayasayı, kurucu iktidarı temsil edecek şekilde tasarlamayı amaçlar.

Almanya örneğinde de Türkiye'de ifade edilen, anti-demokratik ve şiddet yanlısı olarak gördüğümüz görüşün aksine, kurucu iktidar yani halk egemenliği benimsenmekte ve 'anayasal formun/anayasal prosedürün' kurucu iktidarı kısıtlayıcı olmaması gerektiği fikri görülmektedir (Möllers, 2007, s. 87; Can, 2007, s. 103). Möllers (2007), yukarıda verilen görüşü 'anayasal form' ile 'anayasal popülizm' (popülizm kelimesi olumsuz anlamda değil, halka dayanan anlamında olumlu kullanılmıştır) arasındaki ilişki üzerinden formülleştirmekte ve İmparatorluktan günümüz federal Almanya’sına kadar yürütülen tartışmaların da bu yönde ilerlediğini ifade etmektedir (Möllers, 2007; Can, 2007, s. 108).

Yukarıda verilen ülke örneklerinin zıddına günümüzde Türkiye’deki "bazı hukukçuların", yasayı/kanunu toplumsal yönden ve gerçekliğinden uzak, salt prosedürel bir perspektifte yorumladıkları görülmektedir. Prosedür ve hukuki ilkelerin önemi inkâr edilmemekle birlikte; toplumsal boyutunun da hesaba katılarak bütüncül bir bakış açısıyla anayasa gibi, kanunların temelini oluşturan kavramın yorumlanması esas amaçtan uzaklaşmamak adına hayati derecede önemlidir (Dworkin, 1986, s. 14). Toplumsal boyutun, anayasa anlayışına eklemlenmesiyse onun organik bir özellik taşıması anlamına gelmektedir (Can, 2007, s. 108). Yani tarihselciliğin/prosedürcülüğün kısıtlayıcı/durağanlaştırıcı anlayışının ötesinde ve önceki düzenlemenin aksine daha geniş tabanın ihtiyaçlarına, meşruiyetine (Çetin, 2003, s. 62) ve tercihlerine yönelik yapılacak anayasalar, demokrasiye ve anayasanın özüne daha uygun olduğu ifade edilebilir (Dworkin, 1986, s. 364). Kısaca, zamansal boyutun anayasanın meşruiyetini sağlamadığı, meşruiyetin toplumsal tabana ve gerçekliğe bağlı olduğu ve aradaki bağın kuvvetinin meşruiyeti doğurduğu söylenebilir.

Anayasanın belli özel şartlarda ve kişilerce oluşturulması gerektiği, bunların dışında kalanların kurucu iktidar olamayacağ fikrinin, demokrasinin oturmadığı ve aristokrasinin egemen olduğu kısmen yakınçağ, ortaçağ ve öncesine ait olduğu söylenebilir. Yani ‘özel' şartların aranması anti demokratik bir muhteva taşımaktadır (McCormick, 2007). Günümüzde ise bu anlayışın karşısında kurucu iktidar ve halk egemenliği arasındaki ilişkinin sorgulanmasını bir kenara bırakın, küresel ve bölgesel boyutta halk egemenliğin nasıl anayasal düzlemde kurucu iktidar olacağı tartışılmaktadır (Carrozza, 2007; Thornhill, 2012; Lindahl, 2007). Kısaca, Türkiyede mevcut düzenin korunması (statu quo) görüşüne sahip akademisyen, siyasetçi, bürokrat ve benzeri çevrelerin, modern demokrasi anlayışıyla çeliştiği ifade edilebilir. 


\section{Türkiye'de Kurucu İktidar Tartışmaları}

Kurucu iktidar kavramının ve tartışmalarının çıkış yeri olan Batı demokrasileri üzerinden yapılan değerlendirmenin ağırlıklı olarak demokratik bir okuma olduğu görülmüştür. Yapılan tartışmaların, kurucu iktidarın halk egemenliğine dayalı olduğu konusunda değil, bu egemenliğin nasıl tespit edileceği ve çoğunluğun hegemonyası olmaktan nasıl uzak tutulacağı konusunda geliştiği yukarıdaki anlatılanlardan anlaşılmaktadır. Dahası ulusal düzlemde başlatılan düşünsel faaliyetlerin küreselleşmeyle ulus-üstü ve ötesi boyutlara da ulaştığg görülmüştür. Kisaca, ele alınan konu ulusal boyutun ve halk egemenliğinin ötesinde, gerçek bir meşruiyetin nasıl mümkün olacağı yönünde bir seyir izlemektedir.

Teorik incelemenin ardından belli başlı kişi ve yazılar üzerinden Türkiye’deki kurucu iktidar tartışmalarına geçilebilir. Zira Türkiye’deki tartışmalar Batı demokrasilerinde olduğundan farklı bir boyutta ele alınmaktadır. Hatta gerisinde denilebilecek bu tartışmaların kurucu iktidar ve halk egemenliği eşitliğinin sorgulandığı bir seviyede olduğu açıktır. Batı literatürü ile paralel ve tezimizi destekleyici çalışmaların varlığı inkâr edilmemekle birlikte, karşıt görüşlerin hala dillendiriliyor olması bu gerçekliği doğrulamaktadır.

Salt hukuk perspektifinden, hukuksal olmanın yanında siyasal bir belge de olan anayasa tartışmaları yürütülmekte, halk egemenliği prosedürel bir anlayışla göz ardı edilmektedir. Elbette biraz önce de ifade ettiğimiz gibi demokrasiyi ve halk egemenliğini merkeze alan Taha Parla ve Osman Can gibi yazarlar da mevcuttur. Ancak bunların birçoğunu siyaset bilimciler oluşturmakta, anayasa hukukçuları azınlıkta kalmaktadır (Can, 2007, s. 108). Gözler’in (2012) konuyla ilgili kaleme almış olduğu yazı tartışma için uygun bir başlangıç oluşturacaktır. Aynen aktarmak gerekirse, s.

“Aslî kurucu iktidarın, 'hukuk-dışılık've 'sınırsızlık' olmak üzere başlıca iki özelliği vardır Aslî kurucu iktidar, yeni bir anayasa yapmadan önce, varsa mevcut anayasayı ilga ederek hukuk boşluğu ortamı yaratır. Bu ortamda, aslì kurucu iktidarı bağlayacak bir hukuk kuralı yoktur. Bundan sonra aslì kurucu iktidar hiçbir hukuk kuralıyla bağlı olmaksızın, yeniden, sıfırdan (ab initio) bir anayasa yapar Aslî kurucu iktidar, ikinci olarak sınırsız bir iktidardır. Zira hukuk-dışı niteliğini açıkladığımız yukarıdaki paragrafta belirttiğimiz gibi, bu iktidar devrim, hükûmet darbesi gibi olağanüstü durumlarda ortaya çıkmakta, mevcut rejimi devirmekte, anayasayı ilga etmektedir. Böyle bir iktidarı sinırlandırabilecek herhangi bir hukukî kural veya güç yoktur" (Gözler, 2012, s. 47).

Gözler'in yukarıda aynen aktarılan yazısında ve diğer eserlerinde (1998; 2004) kurucu iktidarı aslî ve tali olmak üzere ikiye ayırdığını görmekteyiz. Ancak anlaşılacağı üzere biz bu ayrıma katılmamaktayız. Asli kurucu iktidar olarak tanımlanan kavramın "halk, millet, vatandaş, toplum egemenliği” olduğu, tali iktidar olarak tanımlanan kavramın ise "kurucu meclis" olduğu kanaatindeyiz. Yazarın kurucu iktidarı kendi içinde bölerek yaptığı ayrım yerine biz, kurucu iktidarı yekpare "millet egemenliği” olarak, tali iktidarıysa meşruiyetini halktan alması gereken 
iktidar olarak ayrı ayrı tanımlamaktayız. Görülmektedir ki, Gözler, millet iradesi yerine vesayetin asli kurucu olduğunu ve halkın tali pozisyonda kaldığını ifade etmektedir. Bu temel ayrımdan kaynaklı olarak kurucu iktidardan (millet egemenliği) gücünü alan, demokratik değerlere bağlı ve çoğulcu bir anlayışa sahip bir meclisin, 'kurucu meclis' sıfatı ile yeni baştan bir anayasa oluşturmak dâhil tüm yetkilerini kullanabileceklerini savunmaktayız (Can, 2007, s. 108). Anayasayı değiştirmeyi ve/veya yeni baştan yazmayı mevcut anayasal düzen içerisinde imkânsız görmek (Gözler, 2012, s. 48) kanaatimizce, hukukun özüne aykırı şekline bağlı, statükocu (Çetin, 2003), koyu vesayetçi ve demokratik olmayan bir anlayışı temsil etmektedir (Küçükkaya, 2011, s. 7). Bunun yanında, Gözler, Kurucu İktidar (1998, s. 81-104) adlı eserinde asli kurucu iktidarın demokratik yollarından uzun uzun bahsetmesine karşın, günümüzdeki yeni anayasa tartışmalarına istinaden yazdığı makalesinde buna karşıt bir tutum içerisine girmiştir (Gözler, 2012, s. 52):

\begin{abstract}
"Burada 'halk’in Anayasa tarafindan kurulmadığı, halkın egemen olduğu, aslî kurucu iktidara her zaman sahip olduğu yolunda düşünceler ileri sürülebilir; ancak bu düşüncelerin hukukî bir değeri yoktur. Kaldı ki, 1982 Anayasasının 175'nci maddesi çerçevesinde anayasa değişikliği usulünde, halkoylaması yoluyla iradesini açıklayan organ, 'halk' değil, referanduma gidip geçerli oy kullanan 'seçmenler'dir. Seçmen kavramı ile halk kavramının aynı şey olmadığı ise aşikârdır. Dolayısıyla anayasa değişikliği sürecinde referandum yoluyla iradesini açıklayan seçmen topluluğu, bir aslî kurucu iktidar değil, tali kurucu iktidar, yani bir kurulmuş iktidardır. Kurulmuş bir iktidar olarak da yeni bir anayasa yapma yetkisine sahip değildir" (Gözler, 2012, s. 52).
\end{abstract}

Göztepe’nin (2015) Carl Schmitt’in anayasa öğretisi üzerine kaleme aldığı eserde özetlediği gibi Schmittyen anlayış, kurulan/yapılan anayasanın bir statüko oluşturduğu ve kendini korumak adına 'kurucu iktidarı' sınırlandırması gerektiği düşüncesi hukukçu akademisyenlerin yanında pratik hukukçularda da yaygın olarak görülmektedir. Anayasa yargısı yoluyla mevcut anayasanın muhtevasına, özüne aykırı değişikliklerin önlenmesi gerektiği düşüncesi, seçimle gelen ve anayasayı değiştirebilecek sayıda milletvekiline sahip partilerin bu yolla demokrasinin ve hukukun gereklerine aykırı düzenlemeler yapabilecekleri olasılığından kaynaklandığı ifade edilmektedir (Serim, 1977, s. 33-37). Hatta kaleme aldığımız yazının neredeyse tamamında savunduğumuz halk iktidarı fikri, yukarıda bahsedilen hukukçular tarafından da argüman olarak kullanılmaktadır (Serozan, 1971, s. 137). Bunun yanında, nispeten daha 1lıml fakat yine bazı noktalarda sınırlayıcı bir anlayışın da varlığı bilinmektedir (Turhan, 1976). Ancak bizim savunduğumuz düşünce gerçek anlamıyla meşruiyete sahip, kurucu iktidar (asli) olan halka ve demokratik değerlere dayalı bir anlayıştır. Temsili demokrasinin açıkları üzerinden egemenliği gasp edici ve sayısal üstünlüğü sayesinde halkın egemenliğine tezat teşkil eden uygulamaların onaylanmasını kabul etmek elbette mümkün değildir. Anlatmak istediğimiz önceki halk egemenliğinin, şimdiki halk egemenliğini kısıtlamaması gerektiğidir.

Parlảnın (1984) yaklaşık otuz yıl önce kaleme aldığı makale, aktarmak istediğimiz ve savunduğumuz fikri net bir şekilde özetlemektedir. Gözler'in (1998; 2004; 2012) 'asli kurucu 
iktidar' olarak tanımladığı şeyin, aslında 'kurucu meclis' olduğu, hatta Batılı örneklerinde dahi olağanüstü şartlarda da olsa genel seçime ve partilerin temsiline dayandığı açıkça görülmektedir (Parla, 1984, s. 208). Anlaşılacağı üzere bizim iddiamız Gözler'in “eğer tali kurucu iktidar da yeni bir anayasa yapabilecekse, aslî kurucu iktidar-tali kurucu iktidar seklinde ayrımın bir anlamı kalmaz (2012, s. 49)" söylemine biçimsel olarak uygun, fakat özüne aykırı düşmektedir. Çünkü, Gözler, iki ayrımın gerekliliğini bir ön kabul olarak almakta ve bu ayrım onun tezinin olmazsa olmazını oluşturmaktadır. Parla’nın (1984) yazdıkları bu noktada aydınlatıcı olacaktır:

"Demokrasilerde anayasaların yapılması ve değiştirilmesinde kurucu meclis yönteminin, çeşitli yöntemlerden sadece biri - ve seyrek başvurulan biri- olduğu yakın tarihin incelenmesinde ortaya çıkmaktadır. Batı anayasa hukukunda zaten çok yer tutmayan ve ad hoc (arızî) bir yöntem olarak nitelenen ve Latin Amerika ülkeleri ile totaliter Avrupa'ya özgü kabul edilen bu yöntemin İkinci Dünya Savaşı’nın ertesinde üçönemli Avrupa ülkesinde (Fransa, İtalya, Almanya) kullanılabilmiş olmasının tek açıklaması veya gerekçesi, bu kurucu meclislerin tam anlamıla genel seçim ve partilerin temsili esaslarına dayandırılmış, kısaca geçici parlamentolar kimliğini taşımış olmalarıdır" (Parla, 1984, s. 213).

Aktarılan alıntıda açıkça anlaşıldığı gibi kurucu iktidar tartışması yapılmamakta, kurucu iktidar asli ve tali olmak üzere ayrılmamaktadır. Bunun yanında anayasayı oluşturan iktidarın "kurucu meclis" olduğu, ancak meşruiyetin (doğrudan veya dolaylı olarak, çeşitli demokratik yöntemlerin kullanılmasıyla) halktan alınması gerektiği kaleme alınan makalenin her sayfasında vurgulanmaktadır. Kısaca, Parla, anayasayı değiştirmek veya yeniden oluşturmak için halka dayalı bir meşruiyetin gerekliliğine vurgu yapmakta, herhangi bir olağanüstü durumu meşru görmemektedir. Alıntıda kısmen değinilen, olağanüstü şartları gerekli gören ve bu iradeyi de 'kurucu iktidar' olarak görenlerin aksine, Parla, bahsedilen iradeyi 'kurucu meclis' olarak tanımlamakta ve bunların dahi meşruiyetini 'kurucu iktidardan' yani halktan aldığını söylemektedir (Parla, 1984). Özellikle Fransa örneği üzerinden yürütülen tartışmalara ise şu cevabı vermektedir:

“1958 Beşinci Cumhuriyet Fransa’sına ve Türkiye’de yanlış verilere dayandırılan ve yanlış değerlendirilen De Gaulle olayına gelince, hemen belirtmeliyiz ki, 1958 Fransız anayasası bazılarının sandiğı gibi korporatif veya atanmış bir kurucu meclisin eseri değildir. 1956 genel seçiminden çıkmış bir partiler parlamentosunun ürünüdür. Bu kimliği ile kurucu meclis olarak çalışmış olan 554 üyelik Millet Meclisinin dökümü şöyledir: Komünistler 149, MRP 71, Sosyalistler 90, Radikal Sosyalistler 34, Demokratik ve Sosyalist Birlik 5, Radikaller 33, Sosyal Cumhuriyetçiler 18, Bağımsızlar 95, Öteki Sol 95, Öteki Să̆ 55” (Parla, 1984, s. 215).

Anayasalarımızda da yerini bulan halk/millet egemenliği, anayasa yapma veya değiştirme iddiasında olan meclisler/iktidarlar için demokratik açıdan bir zorunluluktur. Halkın, oluşturulan anayasa üzerindeki kabulü, onun geçerli ve meşru olmasının yanında uzun süre yürürlükte 
kalmasının da anahtarını oluşturacaktır. Halk egemenliğine dayanmayan ve bu yönüyle meşru kabul edilemeyecek anayasaların her ne kadar özgürlükçü ve demokratik olma iddiasında da olsalar, kısa ömürlü oldukları, çözüm yerine sorun ürettikleri yakın geçmişteki tecrübelerden de görülecektir (Parla, 1984, s. 220). 17 Eylül 1787 tarihli Amerikan Anayasası́nın hâlihazırda yürürlükte oluşu da yukarıda verilen görüşü doğrular niteliktedir (The Library of Congress, 2017).

Parla’nın bir siyaset bilimci olması nedeniyle böyle bir görüş beyan ettiği söylenebilir. Her ne kadar biz bu görüşe, anayasanın siyasal nitelikte (Akkanat, 2015, s. 2) fakat hukuksal sonuçları olan bir belge olması sebebiyle katılmasak da Can (2007) gibi konuya hukuki yönden bakarak, yasal zeminin dışına çıkmadan yeni bir anayasa oluşturulabileceğini savunanlar da mevcuttur. Bu görüşe göre, kurucu iktidar bir işlevdir ve yasal sınırlar içerisinde de "tüm parti ve toplumsal güçlerin çağrısıyla ortaya çıkan kurucu bir meclis kurucu iktidar yetkisini kullanabileceği gibi, hâlihazırdaki bir parlamento da bu yetkiyi kullanabilir" (Can, 2007, s. 106). Bunun yanında, mevcut anayasanın da kurucu iktidardan güç alan kurucu meclisi sınırlayamayacağını, hatta aksine sınırlanabileceği yönünde örnek gösterilen Alman Anayasası’nın 146. maddesinde “... bütün Alman halkı için geçerli olan bu Anayasa, Alman halkının serbest iradesiyle kabul edeceği bir Anayasanın yürürlüğe girdiği günde geçerliliğini kaybeder” şeklinde bir ifade açıkça yer almaktadır (Can, 2007, s. 106-107). Kısacası, durağan bir anayasa yerine organik, şartlara ayak uyduran (Güler, 2007, s. 35) ve normatif temellere; yani evrensel demokratik hukuk kaidelerine uygun olarak, yeni baştan anayasa yapımının şiddete başvurmadan barışçıl yollarının da olduğu söylenebilir. Ayrıca "değişstirme olanağının bulunmamasının, meşruiyet zeminini karşı devrime kaydırarak Anayasanın sonunu hazırlayabileceği” ihtimali de unutulmamalıdır (Can, 2007, s. 108).

Anlatılanlardan da anlaşılacağı üzere, Türkiye’deki kurucu iktidar tartışmaları, yeni baştan anayasa yapmanın mümkün olduğunu ancak bunun demokratik ve evrensel hukuk normları içinde (hukuk ilkelerine bağlı fakat yasalardan özgür) mi yoksa bu değerlerin dışında mı gerçekleşebileceği yönünde gelişmiş ve devam etmektedir. Yeni bir anayasanın bir öncekine bağlı kalınmadan yapılabileceği ve bunun demokratik ilkelerin ve hukukun özüne daha uygun olduğu sonucuna ulaşılmıştır.

\section{Kurucu İktidarın Temsili Sorunu ve Referandum}

Kurucu iktidarın küresel alanda teorik ana tartışmalarının verilmesinin ardından, Türkiye’de bu kavram ve türevlerinin ne anlama geldiği ve hangi zemin üzerinde tartışıldığı, kavramın orijinalinde olduğu gibi demokratik kriterler etrafından ele alınmaya çalışılmıştır. Sonuç bölümünde daha detaylı ele alınacağından genel itibari ile tartışmaların, doğrudan demokrasinin aracı olan "referanduma" karşı "statüko" mücadelesi şeklinde cereyan ettiğini özetle ifade edebiliriz. Metinin başından itibaren savunduğumuz gibi kurucu iktidar halkın iktidarıdır ve halkın ihtiyaçları doğrultusunda yeni bir anayasa pek tabi yapılabilir. Yapılacak anayasanın 
demokratik ilkelere bağlı olup olmadığı, bu yetkinin kullanılıp kullanılamayacağıyla ilgili olmayıp farklı bir tartışmanın zeminini oluşturmaktadır. Bizim incelediğimiz konuysa bu iktidarın en iyi şekilde nasıl temsil edileceği ve vücut bulacağıdır. Sorumuzun birden fazla cevabı olduğu kesin olmakla beraber, en somut ve ölçülebilir değer olarak, "doğrudan demokrasinin" bir aracı şeklinde kullanılan referandum kavramı, artısı ve eksisiyle bu başlıkta incelenmiştir.

Antik Yunan'dan bugüne kadar süre gelen demokrasi kavramı, halkın kendi kendini yönetmesi şeklinde tanımlanmıştır. İlk dönemlerde, katılımda bazı sınırlamalar olsa da kapsamın içerisine giren vatandaşların/halkın yönetime doğrudan katıldığı söylenebilir (Abad \& Ursua, 1988, s. 375). Ancak şehir devletlerinin ve sınırlı sayıda halkın katıldı̆̆ı demokratik düzen, günümüzde hem daha kapsamlı bir anlayışa dönüşmüş hem de artan nüfusla ve yönetim birimleriyle daha da karmaşıklaşmıştır. Bunun sonucunda toplumun tamamının yönetime katılımı neredeyse imkânsız hale gelmiştir (Bjorklund, 2009, s. 121). Doğal olarak pratik uygulama alanı daralan halkın kendi kendini yönetmesi olan demokrasi, çoğunluğun yönetimine dönüşmüştür. Yani alınacak kararlarda ve gerçekleştirilecek politikalarda toplumun çoğunluğuna söz hakkı tanıması gerektiği savunulmuştur (Setälä, 2009, s. 1\&4).

Yakın döneme kadar bu anlayışın başta Batı demokrasileri olmak üzere dünyada yaygın olduğunu söyleyebiliriz. Daha sonra bu görüşe karşı eleştiriler yükselmeye başlamıştır. Eleştirilerin ana eksenini, örgütlü bir çoğunluğun diğerleri üzerinde tahakküm kurmasının demokrasinin özüyle bağdaşmayacağı, geri kalanların demokratik haklarına halel getireceği fikirleri oluşturmaktadır (Marxer \& Pallinger, 2009; Setälä, 2009). Çoğulcu demokrasiye yöneltilen bu ithamları etraflıca değerlendirdiğimizde haklı olduklarını görmekteyiz. Toplum genelinin çoğunluğunu oluşturmasa dahi siyasi arenada örgütlü çalışan bir grubun, ayrı ayrı azınlıkta fakat bir bütün olarak çoğunlukta olanlar aleyhinde karar alabilecekleri görülecektir. Bunun yanında, toplumun çoğunluğunu oluşturuyor olsalar da bir grubun diğer grupların aleyhine ve onları tehdit altında birakabilecek kararları almaları pek tabi demokrasiyle bağdaşmamaktadır (Marxer \& Pallinger, 2009, s. 35). Tüm bu gerekçelerden, yakın geçmişimizde 'müzakereci demokrasi' anlayışı doğmuştur. Çoğulcu demokrasinin aksine müzakereci demokrasi tek bir grubun veya grubu oluşturan diğer bileşenlerin doğrusunun hayata geçirilmesi yerine tüm paydaşların bir araya gelerek 'ortak bir doğru' üzerinde buluşmaları, bunun içinse diyalog ve müzakere araçlarının etkin kullanımı öngörmektedir. Böylece, çeşitli sebeplerden dolayı uygulama alanı azalan veya belli noktalarda yok olan halkın kendi kendini yönetmesi şeklinde tanımlanan doğrudan demokrasi anlayışına yaklaşılmış olacaktır (Setälä, 2009, s. 2-3).

Ulaşılmak istenen hedefe yani halkın kendi kendini yönetmesine, müzakereci demokrasinin de tam anlamıyla cevap verdiği söylenemez. Bundan dolayı, yeni çözüm yolları aranmış ve karma bir model üzerinden hem tüm kesimlerin hem de toplumun politika süreçlerine etkin katılımının sağlanması yönünde adımlar atılmıştır. Seçimlerin yalnızca siyasal lideri belirlediği, karar alma süreçlerinde halkın tercihlerinin yansımadığı görüşüne bir cevap olarak üretilen karma modelde, temsili demokrasinin kurumları korunmakla beraber başta referandum olmak üzere çeşitli yollarla sivil katılımın, siyasal katılım ile birlikte 'yönetmesi' amaçlanmıştır (Marxer \& Pallinger, 
2009, s. 35). Özellikle, Avrupa Birliği süreciyle gündeme gelen egemenliğin bir üst yönetime devri, referandumu zorunlu kılmıştır. Çünkü bu durum modern çağın gereklerinden dolayı zaten kısıtlanan halk katılımını daha da güç hale getirmektedir. Her ne kadar referandumlar, çoğunluğun azınlığın üzerinde bazı durumlarda dayatması (Şen, 2012, s. 77-78) gibi görünse de müzakere araçlarının etkin kullanılmasıyla temsili demokrasinin eksiklerini gideren bir özellik ihtiva etmektedir (Setälä, 2009, s. 3-4).

Tablo I: Doğrudan-Demokrasi Araçlarının Uyumlulukları

\begin{tabular}{|c|c|c|}
\hline & Popülist İlke & Anayasal İlke \\
\hline Çoğunluk İlkesi & $\begin{array}{l}\text { Popülist-çoğunlukçu: } \\
\text { - zorunlu referandum } \\
\text { (yeter sayısız) } \\
\text { - geçici ya da isteğe bağlı referandum } \\
\text { (yeter sayısız) }\end{array}$ & $\begin{array}{l}\text { Anayasal-çoğunlukçu: } \\
\text { - zorunlu referandum } \\
\text { (yeter sayısız) } \\
\text { - geçici ya da isteğe bağlı referandum } \\
\text { (yeter sayısız) }\end{array}$ \\
\hline Konsensüs İlkesi & $\begin{array}{l}\text { Popülist-konsensüs: } \\
\text { - popüler inisiyatif } \\
\text { (yeter sayll veya sayısız) } \\
\text { - zorunlu referandum } \\
\text { (yeter sayll) } \\
\text { - istişari referandum } \\
\text { (yeter sayısız) }\end{array}$ & $\begin{array}{l}\text { Anayasal-konsensüs: } \\
\text { - istişari referandum } \\
\text { (yeter sayısız) } \\
\text { - popüler inisiyatif } \\
\text { (yeter sayısız) }\end{array}$ \\
\hline
\end{tabular}

Kaynak: Marxer \& Pallinger, 2009, s. 39'daki tablonun çevirisidir.

Başlı̆̆ın girişinde de ifade ettiğimiz üzere modern dönemde temsili demokrasi, çeşitli yollarla meşruiyeti açısından orijinine yaklaşmayı hedeflemektedir. Halk oylaması veya referandum ise amaçlanan bu hedef doğrultusundaki en somut ve ölçülebilir araç olması dolayısıyla oldukça önemli bir yer tutmaktadır. Yapılış amacına göre referandumu ana hatlarıyla (çeşitli gruplandırmalar yapılsa da) ikiye ayırmak mümkündür (Marxer \& Pallinger, 2009, s. 36). İlki alınan bir kararın onaylanıp-onaylanmadığını tespit etmek, “yerindeliğini” kontrol etmek için yapılan referandum, diğeri ise alınmak istenen karara veya politikaya destek sağlamak yahut politikanın ne denli kabul görüp-görmeyeceğini tespit etmek amacıyla gerçekleştirilmektedir (Abad \& Ursua, 1988, s. 382). Anlaşılacağı üzere, referandum alınan bir karar sonrası olabileceği gibi alınacak karar öncesi de olabilmektedir. Daha açık ifadesi ile birincisi onay-ret veya kontrol işlevi görürken, ikincisi politika yapıcılarına yetki devri veya destek işlevi görmektedir (Setälä, 2009, s. 4-5). Tablo 1'de, açık bir şekilde yapılan, referandum ilkelerinin ayrımları, ayrıntılı olarak görülebilir.

Yukarıdaki amaçsal ayrımın yanında şekilsel bir ayrım da yapılmaktadır. Yasa ve/veya anayasa gereği belli şartlarda yapılması zorunlu olan referandumlar ile beraber politikacıların isteği doğrultusunda özel amaçl1/geçici referandumlar da yapılabilmektedir (Marxer \& Pallinger, 2009, s. 36-37; Şen, 2012, s. 75). Bahsedilen bu yeni gruplandırma bir öncekine zıtlık teşkil etmemekte ve hatta bunların 
farklı birer adlandırması olarak görülebilir. Şöyle ki yukarıdaki kontrol amaçlı referandumlar zorunlu, destek amaçlı referandumlarsa özel amaçlı/geçici referandumlara karşılık gelmektedir. Temsili demokrasiyi güçlendirmesi açısındansa özel amaçli-destek nitelikli referandumların önemine vurgu yapılmaktadır (Bjorklund, 2009, s. 119-120; Rahat, 2009, s. 100). Çünkü bu tür referandumlarda diğerinin aksine alınmış bir karara değil alınacak bir karara katılım söz konusudur. Böylece, oluşturulacak politikada halkın da görüşü alınmış olacaktır. İki ayrımdan hangisinin tercih edildiğinin bir önemi olmakla beraber, referandum konusu işlenirken mutlaka böyle bir ayrımın olduğu unutulmamalıdır (Setälä, 2009, s. 5). Zira referanduma yöneltilen eleştirilerin başında, bireylerin karar almadıkları, alınan karar üzerinde kabul veya ret görüşlerini bildirdikleri dile getirilmektedir. Bu konuda yapılan eleştirilerin haklılık payı inkâr edilemez (Walker, 2003, s. 1). Ancak referandumlar için bu görüşü tümden beyan etmek doğru olmayacaktır.

Referandumun temsili demokrasi açısından önemli bir özelliğinden söz etmemiz de gerekir. Genel ve mahalli seçimlere göre referandumlar, partiye yani genel dünya görüşüne veya adaya değil, politikalara yöneliktir (Bjorklund, 2009, s. 122-123). Seçmenlerin veya reşit halkın görüşlerinin dile getirilmesinde, tartışılmasında ve olgunlaşmasında siyasi parti seçimlerine göre daha sağlıklı bir ortam (politika odaklı) oluşturan referandumlar, bu yönüyle halkın kararlara daha etkin katılmasına olanak tanımaktadır. Ancak referandumların her şart ve durumda olumlu sonuçlar doğuracağını söylemek de gerçekçi bir söylem değildir (Setälä, 2009, s. 7). Tablo 2'de referandumların hangi şartlar altında ne gibi sonuçlara neden olabileceğiyle ilgili olumlu ve olumsuz görüşler özetlenmiştir.

Avrupa özelinde savaş ve komünizmin çöküşünden sonra birçok ülkenin kurucu iktidar söylemiyle yeni anayasal düzenler inşa ettikleri görülmüştür. Olağandışı durumun sonucu olarak olağanüstü yetkilerle gerçekleşen anayasallaşma süreci, geçmişte yaşanan olumsuz tecrübelerden dolayı çoğunluğun anti-demokratik uygulamalarını kontrol etmek amacıyla anayasa korumacılığını da gündeme getirmiştir (Marxer \& Pallinger, 2009, s. 35). Yukarıda ifade edilen zorunlu/anayasa gereği referandumların da bahsedilen amaç doğrultusunda işlev gördüğünü görmekteyiz. Yani kanunların üzerinde konumlanan anayasanın, değiştirilmesi ve yenisinin oluşturulması güçleștirilmiştir. Diğer bir ifade ile referandum, bu amaç doğrultusunda halkın veto yetkisi olarak tanımlanmıştır (Kissane, 2009, s. 22-23). Anayasanın bu yöntem ile kalıcı hale gelip "statükoyu" koruma şekline gelmesi, halkın değişim ihtiyacına olan yoğun talebi sonucunda amaçlananın tersi bir durumla sonuçlanmıştır. Ayrıca, bu durum eski anayasanın dışsal, halk tarafından arzulanan anayasanınsa içsel karakter kazanmasına da neden olmuştur (Kissane, 2009, s. 27; Rahat, 2009, s. 98; Şen, 2012, s. 76).

Daha açık ifadesiyle, elitlerin sistemi durağanlaştırmak maksadıyla kullandığı referandumun, özellikle, 1970'lerden sonra elit bloğa ve onun politikalarına karşı bir veto yetkisine dönüştügüu görülmektedir. Referandumun hem siyasi hem de ekonomik maliyetlerinin, yapılması istenilen değişiklikler için caydırıcı bir faktör olması, ilk zamanlar bu yöntemden uzak durulmasına neden olmuştur (Bjorklund, 2009, s. 119). Ancak daha sonraları ve özellikle Avrupa Birliği sürecinde ülke vatandaşları bu maliyeti satan alarak, elitlerin dayatmasına karşı halk egemenliği lehinde 
kullanmışlardır. $\mathrm{Bu}$ durumun ortaya çıkışında hem mevcut sistem ve temsilcilerinin halkın ihtiyaçlarına cevap verememesi hem de gelişen sivil toplum ve demokrasi anlayışı etkili olmuştur (Bjorklund, 2009, s. 121).

Tablo 2: Temsili Demokrasinin Ana Unsurları Üzerindeki Referandumların Olumlu ve Olumsuz Senaryoları

\begin{tabular}{|c|c|c|c|c|}
\hline $\begin{array}{c}\text { Demokratik } \\
\text { Özellik }\end{array}$ & Ne Anlama Geliyor? & Pozitif Senaryo & Negatif Senaryo & Ana Sorular \\
\hline $\begin{array}{l}\text { Etkin katılım/ } \\
\text { Cevap } \\
\text { verebilirlik }\end{array}$ & $\begin{array}{l}\text { Demokratik } \\
\text { kararlar, vatandaşlar } \\
\text { veya temsilcileri } \\
\text { tarafından ifade } \\
\text { edilen kamuoyunu } \\
\text { yansıtmalıdır. } \\
\text { Vatandaşların siyasi } \\
\text { gündemle ilgili } \\
\text { konuları gündeme } \\
\text { getirme firsatları } \\
\text { olmalıdır. }\end{array}$ & $\begin{array}{l}\text { Referandumlar, } \\
\text { sorunlar üzerinde } \\
\text { kamuoyunu kayıt } \\
\text { altına alır ve böylece } \\
\text { popüler tercihlerin } \\
\text { yanlış beyanatlarını } \\
\text { düzeltir. Popüler } \\
\text { inisiyatifler sorunların } \\
\text { siyasi gündemde } \\
\text { yükselmesine yardımcı } \\
\text { olur. }\end{array}$ & $\begin{array}{l}\text { Referandumlar keyfi } \\
\text { ve tutarsız kararlara } \\
\text { yol açmaktadır. } \\
\text { Referandumlar halk } \\
\text { arasında belirgin } \\
\text { olan konularda } \\
\text { yapılmamaktadır. }\end{array}$ & $\begin{array}{l}\text { Referandumlar, } \\
\text { kamuoyu ve karar alma } \\
\text { arasındaki uçurumu } \\
\text { azaltmaktadır mı? } \\
\text { Referandumlar karar } \\
\text { alma tutarsızlığını } \\
\text { artırıyor mu? }\end{array}$ \\
\hline Müzakere & $\begin{array}{l}\text { Siyasi tercihler, } \\
\text { vatandaşlar veya } \\
\text { temsilcileri arasındaki } \\
\text { özerk düşünceye } \\
\text { ve düşünmeye } \\
\text { dayanmalıdır. }\end{array}$ & $\begin{array}{l}\text { Referandumlar, halkın } \\
\text { bireysel meselelerinin } \\
\text { görüşülmesi için } \\
\text { firsatlar sunar. }\end{array}$ & $\begin{array}{l}\text { Referandumlar, } \\
\text { kamuoyunda } \\
\text { tartışmaların önyargılı } \\
\text { olduğu, müzakereyi } \\
\text { güçlendirmeyen } \\
\text { plebisiter katılım } \\
\text { biçimidir. } \\
\text { Referandumlar, } \\
\text { temsilciler arasında } \\
\text { müzakereyi zayıflatıyor. }\end{array}$ & $\begin{array}{l}\text { Referandum, } \\
\text { müzakere süreçlerini } \\
\text { ne derece ölçüyor? } \\
\text { Referandumlar meclis } \\
\text { görüşmelerini nasıl } \\
\text { etkiler? }\end{array}$ \\
\hline $\begin{array}{l}\text { Temsilcilerin } \\
\text { hesap } \\
\text { verebilirliği }\end{array}$ & $\begin{array}{l}\text { Temsilciler } \\
\text { seçimlerdeki } \\
\text { kararlarından sorumlu } \\
\text { tutulmalıdır. }\end{array}$ & $\begin{array}{l}\text { Referandumlar, } \\
\text { seçilmişlerin } \\
\text { (temsilcilerin) konu } \\
\text { bazında hesap verebilir } \\
\text { olmalarına yardımcı } \\
\text { olur. }\end{array}$ & $\begin{array}{l}\text { Referandumlar, hesap } \\
\text { verme sorumluluğunu } \\
\text { parlamento ve seçim } \\
\text { usullerini bozduğu için } \\
\text { zayıflatmaktadır. }\end{array}$ & $\begin{array}{l}\text { Referandumlar } \\
\text { seçimlerle ve } \\
\text { parlamento usulleriyle } \\
\text { nasil etkileşime giriyor? }\end{array}$ \\
\hline $\begin{array}{l}\text { Sivil } \\
\text { Erdemler }\end{array}$ & $\begin{array}{l}\text { Demokratik } \\
\text { katılım, yurttaşların } \\
\text { yetkinliğini ve siyasi } \\
\text { sorumluluk duygusunu } \\
\text { arttırmaktadır. }\end{array}$ & $\begin{array}{l}\text { Referandumlar } \\
\text { vatandaşları sorunlarda } \\
\text { pozisyon almaya ve } \\
\text { dolayısıyla onların } \\
\text { yetkinliklerini ve siyasi } \\
\text { sorumluluklarını } \\
\text { artırmaya teşvik eder. }\end{array}$ & $\begin{array}{l}\text { Referandum } \\
\text { oylamasında bilgisizlik, } \\
\text { önyargılar vb. yer } \\
\text { almaktadır. } \\
\text { Referandumlar, } \\
\text { toplumsal ve } \\
\text { siyasi çatışmaların } \\
\text { kutuplaşmasına neden } \\
\text { olur. }\end{array}$ & $\begin{array}{l}\text { Vatandaşlar } \\
\text { konuyla ilgili özerk } \\
\text { görüşlerini ne derece } \\
\text { oluşturuyor? Görüşler, } \\
\text { düşünceye ve kamusal } \\
\text { görüşmelere ne derece } \\
\text { dayanmaktadır? }\end{array}$ \\
\hline
\end{tabular}

Kaynak: Setälä, M., 2009, s. 8'deki tablonun çevirisidir. 
Ele alınan konu açısından, elitler ve referandum arasındaki ilişkinin üzerinde biraz daha durulması faydalı olacaktır. Önceki paragrafta anlatıldığg gibi veto yönü ağır basan ve önleyici bir konumda duran referandum, statükoyu korumayı amaçlayan elitler tarafından, doğrudan demokrasi argümanı olarak uzun yıllar savunulmuştur. Ancak müzakere kültürünün ve demokratik kültürün oluşması ile toplumdaki demokratik oluşum ve unsurların ülke yönetimi ve diğer politikalara yönelik düşüncelerini sistemli ve 1srarlı ifade etmeleri, referanduma karşı vesayetçi ve statükocu elitist muhalefetin de yükselmesine neden olmuştur. Devletin ideolojik aygitlarını kontrolü altında tutan elitler, toplumu kolayca yönlendirebilmekte ve/veya toplumu hizipleştirerek muhalif seslerin güçlenmesini önleyebilmekteydi (Althusser, 2000; Walker, 2003, s. 1-2).

Bu gücün zayıflaması ve sivil inisiyatiflerin yükselmesiyle elitler, bu sefer de referandumun toplumu temsil etmeyen çoğunluğun görüşlerinin tahakkümü olduğu eleştirilerine dayanarak karşı bir duruş almışlardır. Ancak statükonun korunması adına, çoğunluğun oyunu ve toplumsal meşruiyeti arkasına alan seçilmiş siyasilerin yapmak istedikleri reformlara karşı da -seçimin hem oy hem de ekonomik maliyetinden dolayı seçilmiş iradenin bu maliyeti göze alamayacaklarını düşündükleri durumlarda- referandum yanlısı pozisyon alabildiklerini unutmamak gerekir (Rahat, 2009, s. 98). Elitler, seçimler ve siyasiler üzerinden yapılan referandum değerlendirmesini özetlemek gerekirse, toplumun sahip olduğu demokratik kültürün ve diğer demokratik argümanların işlerliği, referandumun ne ölçüde halka dayandığını ve politikaları meşru kıldığını belirlemektedir. Diğer tüm demokratik araçların sağlanmadığı ve sivil toplumun zayıf olduğu durumlarda referandum, yalnızca, halkın edilgen kaldığı ve elitler ile siyasi aktörlerin yaptığ 1 pazarlıktan öte bir anlama gelmeyecektir (Walker, 2003).

Referandum konusunu ele aldığımız bölümün başından itibaren bir ideal olarak doğrudan demokrasinin gerçekleştirilmesi yönünde temsiliyete dayanan çoğunlukçu sistemden müzakereci demokrasiye kadar çeşitli çabaların olduğunu söylemiştik. Konumuz olan referandumun da ideal demokrasi için bir araç ve halkın yönetime doğrudan katılımının mümkün olduğunca sağlanması yönünde bir adımdır. Elitist ve patrimonyal anlayışın halkı küçümseyici eleştirilerini bir kenara birakırsak (Rahat, 2009; Walker, 2003; Bjorklund, 2009), halk iradesinin ülke yönetimine ne derece katıldığı, ülkenin demokratikleşme seviyesini göstermektedir. Tam bu noktada halkın politikaların onaylanıp onaylanmaması yahut bir konu hakkında eyleme geçilip geçilmemesi konusunda, doğrudan karar vermesini mümkün kılan, referandum oldukça önemli bir yer tutmaktadır (Yeşilorman, 2011, s. 192-193; Setälä, 2009).

Türkiye siyasetinin özellikle 2007'den sonraki gündeminde de referandumun oldukça önemli konular arasında yer aldığını görmekteyiz. Pratik anlamda 27 Mayıs askeri darbesinden sonra 1961 Anayasası̉nın referanduma sunulmasıyla Türk toplumunun tanıştığı referandum, 12 Eylül askeri darbesinin ardından yine bir anayasa oylaması şeklinde yeniden uygulanmış ve 1982 Anayasası'nda anayasa değişiklikleri ile ilgili belirli şartlarda uygulanması öngörülerek anayasal bir zemine kavuşmuştur (Yeşilorman, 2011, s. 205). Türkiye örneği bu yönüyle yukarıda gruplandırılan referandum türlerinden zorunlu, onay-ret ve önceden alınmış bir karara karşı 
verilen cevap şeklinde olan referandumlara uygun düşmektedir. Politika yapıcıların, karar öncesinde alınması düşünülen karara yönelik bir yetki talebi veya halkın talebi doğrultusunda uygulanan bir referandum olmadığı çok açıktır (Setälä, 2009). Bu açıdan değerlendirildiğinde Türkiye'deki uygulamanın, darbeler sonrası ve darbelerin de 'rot balans' işlevi (Akbey, 2005, s. 29) görmesi dolayısıyla 'elitlerin' mevcut durumu muhafaza etme yolunda zorlaştırıcı bir aracı olarak görülebilir (Kissane, 2009).

İlki 1961 yılında, sonuncusu (ve 2016 yılı itibariyle) 2010 yılında olmak üzere toplamda altı defa referanduma gidilmiş ve bunlardan biri hariç (1988 yılında yapılan ve yerel seçimlerin erkene alınmasıyla ilgili) tümü kabul edilmiştir. Kabul edilmeyenin belli ve geçici bir durum için olduğu, diğerlerinin ise kalıcı ve siyasal anlamda önemli kararlar olduğu rahatlıkla söylenebilir. Hatta böyle bir tabloyu, 'Türkiye'deki referandumları statükocu ve iktidar yanlısı' şeklinde yorumlayanlar da vardır (Yeşilorman, 2011, s. 206-207). Türkiye'de yapılan referandumlar için böyle bir yorum yapılmasını yukarıda da bahsettiğimiz 'elit blok' argümanıyla açıklamak doğru olacaktır. Böylesi bir durumda kararların blok içerisinde alındığı, halkın edilgen pozisyona itildiği ileri sürülmektedir (Althusser, 2000; Walker, 2003, s. 1-2; Bowler \& Donovan, 2001, s. 128-129). Elbette ki demokrasi adı altında aristokratik ve 'arızalı' bir yapı inşa eden bu anlayış ve uygulama kabul edilemez. Bu noktada, Budge’ın (2001) siyasal partilerin doğrudan demokrasi, yani referandumlar üzerinde yönlendirici olduğu yönündeki bulgusu akla gelmektedir. Budge’a göre demokrasinin gelişmediği, sivil inisiyatiflerin ve ad hoc/isteğe bağh referandumların az olduğu veya hiç olmadığı, zorunlu referandumların ağırlıklı uygulandığı ülkelerde, siyasi partilerin sonuçları etkileyebildiği, daha doğrusu alınan kararın yalnızca onaylanması şeklinde geliştiği tespit edilmiştir (Budge, 2001, s. 78-83). Hatta Bowler \& Donovan’ın (2001) tanımlamasında yahut gruplandırmasında Türkiye'deki halk oylamalarının hepsine referandum demek doğru olmayacaktır. Özellikle, 27 Mayıs ve 12 Eylül cuntalarının ürünü olan anayasalar için gerçekleşen halk oylaması, anti-demokratik uygulamaların, yasalarm, anayasaları yine anti-demokratik bir ortamda halka kabul ettirildiği birer plebisit oylamalardır (Bowler \& Donovan, 2001, s. 128).

Tüm anlatılanları daha yalın ifade edilecek olursa, referandumların özü itibariyle halkın yönetime katılımını sağlaması gerekmektedir. Ancak Türkiye ve benzeri ülkeler, referandumu devlet/parti merkezli olarak görmekte, uygulamaktadır. Bu durum referandumun, sinırlı anlamı ile anayasada yer almasından kaynaklanmaktadır. Zorunlu durumların dışında, partilerin, alınacak kararlarda halkın görüşünün ne olduğunu tespit etmek amacıyla isteğe bağlı referandumlarla, halkın kendi inisiyatifleriyle gündeme getirdikleri referandumlar, vesayetçi anlayışın ortadan kaldırmasında ve gerçek anlamıyla kurucu iktidarın yani halk egemenliğinin sağlanmasında oldukça önemli bir yere sahiptir (Şen, 2012, s. 77; Bowler \& Donovan, 2001, s. 128; Budge, 2001, s. 78-83). Türkiye'deki referandumun yalnızca zorunlu olmasının yanında bir diğer sorunlu yönüyse her anayasa değişikliğinin referandumu gerektirmemesi (330-367 kabul oyu arasında zorunlu, 367 ve yukarısı ise değil) ve bu yetkinin sadece Cumhurbaşkanında olmasıdır. Özellikle, son on yılda -2007 yılındaki anayasa değişikliği sonrasında 2014’te doğrudan seçimle işbaşına gelmesine kadar halka karşı hiçbir siyasi sorumluluğu olmayan rejimin muhafızı şeklinde görev yapanCumhurbaşkanının, seçimler yoluyla halka hesap veren iktidarı işlevsiz hale getirdiğine şahit 
olunmuştur (Milliyet, 2016). Bunun yanında kendisini 'kurucu aklın' temsilcisi gören siyasi, adli, askeri ve bürokratik kanadın çizginin dışına çıkan kararlara karşı bir ittifak halinde oldukları da görülmüştür (Akbey, 2005, s. 29; Milliyet, 2016; Anayasa Mahkemesi, 2007).

Bu çalışmanın kaleme alındığı tarihlerde, henüz Türkiye Büyük Millet Meclisi’nde görüşülüyor olmasından dolayı 21 maddelik $^{1}$ anayasa değişikliği teklifinin (NTV, 2016) incelenmesinden akademik hassasiyetlerden dolayı kaçınılmıştır. Ancak 'değişiklik yapabilme hakkı' üzerinden yöneltilen eleştirileri, halk iktidarı açısından ele almakta fayda olacağı kanaatindeyiz. Geçmiş dönemde Necmettin Erbakan'ın da dile getirdiği 'Kanlı mı? Kansız mı?' sorusunun işaret ettiği gibi, güncel anayasa değişikliği ve başkanlık sistemi tartışmalarında demokratik meşru yollarla muhalefet edilmek yerine sistemin ve anayasa değişikliğinin kan dökülmeksizin yapılamayacağ yönünde bazı siyasilerin açıklamalar yaptığı görülmektedir (Süzer, 2016). Bunun yerine getirilen teklifin, içeriği üzerinden yani kuvvetler ayrılığı, temel hak ve hürriyetler başta olmak üzere demokratik kriterler etrafında eleştirilmesi daha doğru olacaktır (Gözler, 2016).

\section{Sonuç}

Halk egemenliğinin, demokrasinin omurgasını ve hatta varlık sebebini oluşturduğunu söylemek çok da iddialı bir cümle olmayacaktır. Hukukun da demokratik değerlere saygılı ve onun teminatı olması gerektiği bu düşünceyle paralellik arz etmektedir. Dolayısıyla, kurucu iktidar olarak halk, nasıl yönetilmesi gerektiği konusunda kendisi karar vermelidir. Batı literatüründe kurucu iktidar kavramının bu düşünceyle benzerlik gösterdiği görülmüştür. Egemenliğin halka ait olduğuna ilişkin her hangi bir şüphenin olmadığı batı literatüründe, anayasanın meşruiyetini halk egemenliğinin oluşturduğu ortak bir görüştür. Ancak oluşturulan anayasa üzerinde bazı düşünürlerce yine demokratik hassasiyetler ve geçmişteki acı tecrübelerden dolayı her çoğunluğu elinde bulunduranın demokrasinin özüne aykırı düzenlemeler yapması engellenmeye çalışılmış, bu yönde denge-fren mekanizmaları öngörülmüştür. Bu durumda dahi korunmak istenenin statüko değil, halkın kendisi olduğu unutulmamalıdır.

Türkiye'deki kurucu iktidar söylemlerinde ise savaş, istila ve benzeri olağanüstü durumların kurucu iktidarı sağlayacağı görüşü hâkimdir. Siyaset kökenli akademisyenlerin ve bazı hukukçuların dışında, bu görüşün yaygın olduğu görülmüştür. Bunun yanında batı literatürünün kurucu meclis olarak gördüğü olağanüstü durumlarda ortaya çıkan anayasa yapıcılarını, Türkçe literatür kurucu iktidarmış gibi sunmaktadır. Makalede sık sık vurgulandığı üzere, kurucu iktidar halkın kendisi olup, bu gücünü devrettiği temsilcileri aracılığıyla yerine getirmektedir. Halkın etkin katıldığı ve tüm fikirlerin özgürce ifade edildiği barış ortamında oluşturulması gereken ve toplumsal mutabakat sözleşmesi olarak görülen anayasanın, Türkiye’de bir takım yazarlar ve siyasetçilerce, kısacası elitlerce, anti-demokratik şartlarda oluşturulması gerektiği savunulmaktadır. Hatta

$1 \quad$ Anayasa Komisyonu’na 21 madde olarak gelen anayasa değişikliği, komisyon görüşmelerinin ardından 18 maddeye düşmüştür (BBC 2016). Burada süreç bir bütün olarak düşünüldüğünden ve henüz devam ettiğinden teklifin ilk halinden bahsedilmiştir. 
güncel tartışmalardan da görüleceği üzere, "kan dökülmeden” anayasanın değiştirilemeyeceği tehditleri meşru iktidarlara yöneltilmektedir.

Ülkemizde hali hazırda süreci devam eden anayasa tartışmalarına farklı bir boyut kazandırmayı amaçlayan bu çalışma; yeni bir anayasa yapma hakkının seçilmiş bir iradenin elinde olduğu, eleştirilerin bu yetki üzerinden değil anayasa teklifinin içeriği üzerinden demokratik bir okuma şeklinde olması gerektiğini savunmaktadır. 'Yapamazlar' ikazının değil, bu anayasa teklifinin toplumsal meşruiyetinin ne olduğu, hangi tarafların görüşlerinin alındı̆̆ı, insan hak ve hürriyetlerine ne denli bağlı kaldığı gibi temel soruların muhalefet söyleminde yer alması gerekmektedir. Ancak son yıllarda bu sürece ilişkin muhalefet, 'yapamazsınız, yetkili değilsiniz, kurucu iktidar olamazsınız" şeklinde cereyan etmiştir. Anayasa değişikliği teklifinin Anayasa Komisyonuna geldiği zaman, yukarıda belirtilen eleştirilerin yapıldığ görülmektedir. Başından itibaren bu işi meşru görmediklerini söyleyerek, halk iradesine ipotek koymaya çalışan vesayetçi elitlerin son girişimlerinin, demokratik kaygılardan öte "statükocu” bir kaygının eseri olduğu açıktır.

Yapılacak anayasa değişikliğinin -elitlerin süreci bloke etmek amacıyla fikir alışverişine yanaşmaması dolayısıyla- meşruiyeti ancak meclisteki çoğunluğun mutabakatıyla ve referandumla sağlanacak gibi görünmektedir. Türkiye’ye batılı ülkelerin aksine, yalnızca zorunlu referandumların olması dolayısıyla, diğer sivil katılım yollarının resmi olarak kullanılıp tam anlamıyla meşruiyet zemininin sağlanamadığı eleştirisi yöneltilebilir. Ancak iktidar partisi, özellikle 2007 yılından bu yana yeni bir anayasa oluşturacağını genel ve yerel seçimlerde ifade etmiş, seçimlerde de bu politikasıyla oylanmıştır. Bunun yanında, diğer kesimlerin katılımına açık pek çok girişimde de bulunulmuş, ancak bu girişimlere elitlerin blokaj uyguladıkları da görülmüştür. Kısaca, iktidar partisi, anayasa değişikliğini toplumsal tabana yayma konusunda elinden geldiği kadarıyla gayret göstermiştir. Bu çalışmada sonuç olarak, batıda referandumlara yöneltilen eleştirilerin Türkiye’de geçerli olmadığını, halkın referandum sonucunda nihai kararı vereceğini ve kararın bu şartlar altında meşru olacağı kanaatine ulaşılmaktadır. 


\section{Kaynakça}

Abad, A.M.D. \& Ursua, E.G. (1988). "Initiative and Referendum an Experimentation at People Empowerment”, Philippine Law Journal, 63, 375-402.

Akbey, F. (2005). "Küreselleşme ve Türkiye’de Kamu Ekonomisi, Devlet-Piyasa-Toplum İlişkilerinde Dönüşüm”, içinde L. Özmen, M. A. Sözer, \& İ. Şahin (der.), 21. yy. da Türkiye’ de Sosyal Bilimler ve Toplum Sorunlar Sempozyumu, Ankara: Akademisyenler Birliği, 21-43.

Akkanat, S. (2015). “Kurucu İktidara Dayalı Bir Demokrasinin İmkânı: Siyasal Bir Yaklaşım”, Amme İdaresi Dergisi, 48 (2), 1-21.

Althusser, L. (2000). İdeoloji ve Devletin İdeolojik Aygıtları, Türkçe. Y. Alp \& M. Özışık (eds.), İstanbul: İletişim Yayınları.

Anayasa Mahkemesi (2007). “Anayasa Mahkemesi Kararı”, Resmi Gazete, Erişim: http://www.resmigazete. gov.tr/eskiler/2007/08/20070807-13.htm [E.T. 29.12.2016].

BBC, 2016. Anayasa değişiklik teklifi Komisyon'dan geçti, www.bbc.com. Erişim: http://www.bbc.com/turkce/ haberler-turkiye-38465427 [E.T. 30.12.2016].

Bjorklund, T. (2009). “The Surge of Referendums and the New Politics Approach”, in M. Setälä \& T. Schiller (eds.), Referendums and Representative Democracy: Responsiveness, Accountability and Deliberation, New York: Routledge Taylor \& Francis Group, 117-136.

Boucher, D. \& Kelly, P. (1994). "The Social Contract and its Critics: An Overview", in D. Boucher \& P. Kelly (eds.), The Social Contract from Hobbes to Rawls, London: Routledge Taylor \& Francis Group, 1-34. Erişim: http://www.jstor.org/stable/1060972?origin=crossref.

Bowler, S. \& Donovan, T. (2001). "Popular Control of Referendum Agendas: Implications for Democratic Outcomes and Minority Rights", in M. Mendelsohn \& A. Parkin (eds.), Referendum Democracy: Citizens, Elites, and Deliberation in Referendum Campaigns, London: Palgrave Macmillan, 125-146.

Böckenförde, E.-W. (1997). “The Concept of the Political: A Key to Understanding Carl Schmitt's Constitutional Theory", Canadian Journal of Law and Jurisprudence, 10 (1), 5-19.

Budge, I. (2001). "Political Parties in Direct Democracy", in M. Mendelsohn \& A. Parkin (eds.), Referendum Democracy: Citizens, Elites, and Deliberation in Referendum Campaigns, London: Palgrave Macmillan, 67-87.

Can, O. (2007). “Anayasayı Değiştirme İktidarı ve Denetim Sorunu”, Ankara Üniversitesi SBF Dergisi, 62 (3), 101-139.

Carrozza, P. (2007). “Constitutionalism's Post-Modern Opening”, in M. Loughlin \& N. Walker (eds.), The Paradox of Constitutionalism: Constituent Power and Constitutional Form, New York: Oxford University Press, 169-188.

Colón-Ríos, J. (2014). “Constituent Power, The Rights of Nature, and Universal Jurisdiction”, McGill Law Journal, 60 (1), 127-172.

Colón-Ríos, J. (2010). "Legitimacy of the Juridical: Constituent Power, Democracy, and the Limits of Constitutional Reform”, Osgoode Hall Law Journal, 48 (2), 199-245.

Corrias, L. (2016). "Populism in a Constitutional Key: Constituent Power, Popular Sovereignty and Constitutional Identity", European Constitutional Law Review, 12 (1), 6-26. Erişim: http://www. journals.cambridge.org/abstract_S1574019616000031.

Cristi, R. (1997). "Carl Schmitt on Sovereignty and Constituent Power", Canadian Journal of Law and Jurisprudence, 10 (1), 189-201.

Çetin, H. (2002a.) "Egemenlik ve Hukuk İlişkisi Üzerine”, C.Ü. İktisadi ve İdari Bilimler Dergisi, 3 (2), 1-16. 
Çetin, H. (2002b). “Modern Devletin Egemenlik (Kurucu İktidar) Döngüsü”, Abant İzzet Baysal Üniversitesi Sosyal Bilimler Enstitüsü Dergisi, 5 (5), 56-75.

Çetin, H. (2003). “Siyasetin Evrensel Sorunu: İktidarın Meşruiyeti-Meşruiyetin İktidarı”, Ankara Üniversitesi SBF Dergisi, 58 (3), 61-88.

Demirkent, D. (2015). “Anayasal Kuruluş Konusunda Kapanmayacak Tartışma: Hannah Arendt ve Carl Schmitt’te Kurucu İktidar Sorunu”, Mülkiye Dergisi, 39 (3), 89-122.

Dworkin, R. (1995). "Constitutionalism and Democracy", European Journal of Philosophy, 3 (1), 2-11.

Dworkin, R. (1986). Law's Empire, Massachusetts: Harvard University Press.

Dworkin, R. (1973). “The Original Position”, The University of Chicago Law Review, 40 (3), 500-533.

Dyzenhaus, D. (2007). “The Politics of the Question of Constituent Power", in M. Loughlin \& N. Walker (eds.), The Paradox of Constitutionalism: Constituent Power and Constitutional Form, New York: Oxford University Press, 129-146.

Erhürman, T. (2013). “Birleşik Krallık’ta Parlamento Egemenliği İlkesinin Dönüşümü”, içinde M. Öden et al. (der.), Prof. Dr. Erdal Onara Armağan Cilt- I, Ankara: Ankara Üniversitesi Yayınları, 257-282.

Gauthier, D. (1977). “The Social Contract as Ideology”, Philosophy \& Public Affairs, 6 (2), 130-164. Erişim: http://www.jstor.org/stable/2264939.

Gözler, K. (2004). Anayasa Hukukuna Giriş, Bursa: Ekin Kitabevi Yayınları. Erişim: www.anayasa.gen.tr/ kiktidar.htm.

Gözler, K. (2012). "Aslî Kurucu İktidar - Tali Kurucu İktidar Ayrımı: TBMM Yeni Bir Anayasa Yapabilir mi?” içinde E. Göztepe \& A. Çelebi (der.), Demokratik Anayasa: Görüşler ve Öneriler, İstanbul: Metis Yayınları, 45-61.

Gözler, K. (2016). "Elveda kuvvetler ayrıllğı, Elveda anayasa: 10 Aralık 2016 Tarihli Anayasa Değişikliği Teklifi Hakkında Bir Eleştiri”, www.anayasa.gen.tr. Erişim: http://www.anayasa.gen.tr/elveda-anayasa-v2. htm [E.T. 29.12.2016].

Gözler, K. (1998). Kurucu İktidar, Bursa: Ekin Kitabevi Yayınları.

Göztepe, E. (2015). “Bir Klasik Eser Olarak Carl Schmitt’in 'Anayasa Öğretisi”, İstanbul Üniversitesi Hukuk Fakültesi Mecmuası, 73(1), 129-180. Erişim: http://www.journals.istanbul.edu.tr/iuhfm/article/ view/5000175197.

Griffin, S. M., (2007). "Constituent Power and Constitutional Change in American Constitutionalism", in The Paradox of Constitutionalism: Constituent Power and Constitutional Form, 49-66.

Güler, G.Y. (2007). “Anayasa Değişiklikleri, Kurucu İktidarlar ve Meşruiyet”, Sayıştay Dergisi, (66-67), 3546.

Habermas, J. (1995). “On the Internal Relation Between the Rule of Law and Democracy”, European Journal of Philosophy, 3 (1), 12-20.

Hekimoğlu, M.M. (2007). “Bu Meclis Anayasa Yapabilir mi?”, Finans Politik \& Ekonomik Yorumlar, 44 (511), 8-11.

Jaume, L. (2007). “Constituent Power in France: The Revolution and its Consequences", in M. Loughlin \& N. Walker (eds.), The Paradox of Constitutionalism: Constituent Power and Constitutional Form, New York: Oxford University Press, 67-86.

Kalyvas, A. (2005). "Popular Sovereignty, Democracy, and the Constituent Power", Constellations, 12 (2), 223-244.

Kissane, B. (2009). “From People's Veto to İnstrument of Elite Consensus: The Referendum Experience in Ireland", in M. Setälä \& T. Schiller (eds.), Referendums and Representative Democracy: Responsiveness, Accountability and Deliberation, New York: Routledge Taylor \& Francis Group, 17-33. 
Klein, C. (1978). "Is There a Need For an Amending Power Theory?", Israel Law Review, 13 (2), 203-214.

Küçükkaya, H. (2011). "Şiddeti Doğuran Bir Faktör Olarak Kurucu İktidar Sorunsalı”, II. Hukukun Gençleri Sempozyumu: Şiddet Döngüsünü Kırmada Hukukun Rolü, Ankara: Umut Vakfı Araştırma Merkezi. Erişim: www.umut.org.tr.

Lindahl, H. (2007). “The Paradox of Constituent Power. The Ambiguous Self-Constitution of the European Union”, Ratio Juris, 20 (4), 485-505.

Loughlin, M. (2007). "Constituent Power Subverted: From English Constitutional Argument to British Constitutional Practice", in M. Loughlin \& N. Walker (eds.), The Paradox of Constitutionalism: Constituent Power and Constitutional Form, New York: Oxford University Press, 27-48.

Loughlin, M. (2014). "The Concept Of Constituent Power", European Journal of Political Theory, 13 (2), 218-237. Erişim: http://ept.sagepub.com/cgi/doi/10.1177/1474885113488766.

Loughlin, M. \& Walker, N. (2007). "Introduction”, in M. Loughlin \& N. Walker (eds.), The Paradox of Constitutionalism: Constituent Power and Constitutional Form, New York: Oxford University Press, $1-8$.

Marxer, W. \& Pallinger, Z.T. (2009). "Stabilizing or destabilizing? Direct-democratic instruments in different political systems", in M. Setälä \& T. Schiller (eds.), Referendums and Representative Democracy: Responsiveness, Accountability and Deliberation, New York: Routledge Taylor \& Francis Group, 3455 .

McCormick, J.P. (2007). "People and Elites in Republican Constitutions, Traditional and Modern", in M. Loughlin \& N. Walker (eds.), The Paradox of Constitutionalism: Constituent Power and Constitutional Form, New York: Oxford University Press, 107-128.

Milliyet (2016). Ahmet Necdet Sezer. www.milliyet.com.tr, Erişim: http://www.milliyet.com.tr/ahmetnecdet-sezer/ [E.T. 29.12.2016].

Möllers, C. (2007). “We are (Afraid of) the People: Constituent Power in German Constitutionalism”, in M. Loughlin \& N. Walker (eds.), The Paradox of Constitutionalism: Constituent Power and Constitutional Form, New York: Oxford University Press, 87-106.

NTV (2016). Anayasa Değişikliği Teklifi (21 Maddenin Tamamı).www.ntv.com.tr.Erişim:http://www.ntv.com. tr/galeri/turkiye/anayasa-degisikligi-teklifi-21-maddenin-tamami,oc7bS2xYZ0KeBEN94ml-NA/ z3aTW7sU7Uqms_CM-NvVFQ [E.T. 29.12.2016].

Özmen, B. \& Özdemir, H. (2011). “Türk Anayasacılık Tarihinde Anayasal Kurucu İktidar (Bulgaristan Büyük Ulusal Meclisi Örneği ve Türkiye Cumhuriyet Meclisi Önerisi)”, e-Journal of New World Sciences Academy, 6 (4), 869-888.

Öztürk, A. (2013). "Machiavelli Düşüncesinde Cumhuriyetçi Özgürlük ve Kurucu Lider İmgesi”, Ankara Üniversitesi SBF Dergisi, 68 (2), 181-204.

Parla, T. (1984). “Anayasalar ve Kurucu Meclisler Üzerine Bazı Karşılaştırmalı Notlar”, İktisat Fakültesi Mecmuasl, 38 (3-5), 207-221.

Preuss, U.K. (1993). "Constitutional Powermaking for the New Polity: Some Deliberations on the Relations between Constituent Power and the Power and the Constitution", Cardozo Law Review, 14 (639), 639-660.

Rahat, G. (2009). “Elite Motives For Initiating Referendums: Avoidance, Addition And Contradiction”, in M. Setälä \& T. Schiller (eds.), Referendums and Representative Democracy: Responsiveness, Accountability and Deliberation, New York: Routledge Taylor \& Francis Group, 98-116.

Schmitt, C. (2008). Constitutional Theory, Translated. J. Seitzer, (ed.), Durham: Duke University Press.

Serim, E. (1977). “Anayasa’yı Değiştirme Sorunu”, Ankara Barosu Dergisi, 1977 (1), 33-37. 
Serozan, R. (1971). “Anayasayı Değiştirme Yetkisinin Sınırları”, İstanbul Üniversitesi Hukuk Fakültesi Mecmuasl, 37 (1-4), 135-141.

Setälä, M. (2009). "Introduction", in M. Setälä \& T. Schiller (eds.), Referendums and Representative Democracy: Responsiveness, Accountability and Deliberation, New Jersey: Routledge Taylor \& Francis Group, 1-14.

Spång, M. (2014). Constituent Power and Constitutional Order: Above, Within and Beside the Constitution, London: Palgrave Macmillan.

Stacey, R. (2011). "Constituent power And Carl Schmitt's Theory Of Constitution in Kenya's ConstitutionMaking Process", International Journal of Constitutional Law, 9 (3-4), 587-614.

Süzer, E. (2016). "Kılıçdaroğlu: Başkanlığı Kan Dökmeden Getiremezsin”, Sözcü, Erişim: http://www.sozcu. com.tr/2016/gundem/kilicdaroglu-tobbda-1224998/ [E.T. 29.12.2016].

Şen, İ.G. (2012). "Doğrudan Demokrasi Aracılığıyla Siyasal Katılımı Artırmak: Referanduma Dair Sorunlar ve Çözüm Önerileri”, içinde İ. G. Şen (der.), Demokrasi ve Siyasal Katılım, İstanbul: Heinrich Böll Stiftung Derneği Türkiye Temsilciliği, 75-85.

The Library of Congress (2017). United States Constitution. Erişim: http://www.loc.gov/rr/program/bib/ ourdocs/Constitution.html [E.T. 23.02.2017].

Thornhill, C. (2012). "Contemporary Constitutionalism and the Dialectic of Constituent Power", Global Constitutionalism, 1 (3), 369-404.

Turhan, M. (1976). "Anayasaya Aykırı Anayasa Değişiklikleri”, Ankara Üniversitesi Hukuk Fakültesi Dergisi, $33(1), 63-104$.

Turinay, F.Y. (2011). “Bir Kelime Olarak 'Anayasa’nın Tarihsel Yolculuğu Üzerine Düşünceler”, TBB Dergisi, 95, 269-312.

Walker, M.C. (2003). The Strategic Use of Referendums: Power, Legitimacy, and Democracy, New York: Palgrave Macmillan.

Yeşilorman, M. (2011). "Halkın İradesi Bağlamında Halkoylamaları: Bir Hukuk Sosyolojisi Denemesi”, Sosyoloji Konferanslarl, (43), 191-220. 
